\title{
IPWordles $^{1}$
}

\author{
Nancy K. Roderer \\ Johns Hopkins University, Baltimore, MD, USA \\ E-mail: nroderer@jhmi.edu
}

For me, it's all about the overlap - those characteristics of different information professions that remain consistently prominent whichever particular profession you are considering. The differences are important, too, and account for the fact that there are many titles and educational programs, but my primary interest lies in underscoring the similarities and through this bringing the information professions into partnership.

What commonalities should we look for? Were these professions with rich underlying theory, we might look there, and I hope that someday we will be able to do this. We might also, someday, look for shared beliefs and strategies. But a practical approach, especially for those who work to educate information professionals, is to look for shared skills or competencies. This is an approach that has been proposed by the ASIS\&T Information Professionals task force, but largely remains to be done. This paper is an exploratory look at a set of information professions, using word clouds, and my hope is that it will lead to some creative sparks and further work on shared skills.

My methods were to identify information professions of interest, find authoritative statements of educational goals, and to create word clouds from them. A word cloud is a visual representation for text data, typically used to visualize free form text. I used wordle.net to create my word clouds. The results are shown in Figs 1-11. The documents I identified covered a wide range of dates, from the ASIS\&T Educational Guidelines of 2001 to a recent job description for a user experience librarian. When I could not identify an authoritative statement, I used job descriptions. There is some, but not much, variation that would seem to be attributable to the time or the source of publication.

My choice of information professions was idiosyncratic. In addition to ones that are general, and others that group around librarianship, I included several from the health sciences, where I practice. Finally, I included some information professions with titles of recent origin, including user experience director and data scientist. It is my hope that you, the reader, will wonder about how other information professions would be represented, and will create your own word clouds.

Reviewing the word clouds, I looked for the most prominent words. I also looked for occurrences of:

- data, information, knowledge - the essentials,

- resources, systems/technology, users, services - the components,

- creating, organizing, providing, managing, analyzing - verbs,

- organization, society - context.

\footnotetext{
${ }^{1}$ This work is licensed under the Creative Commons Attribution-Noncommercial No Derivations Works 3.0 Unported license. You are free to Share this work (copy, Distribute and transmit) under the following conditions: attribution, noncommercial and no derivative works. To view a copy of this license, visit http://creativecommons.org/licenses/by-nc-sa/3.0/.
} 
It is my hope that as you look at these IP word clouds that you will see other patterns, and that they will collectively inspire us on to further investigation of the commonalties and differences among the information professions.

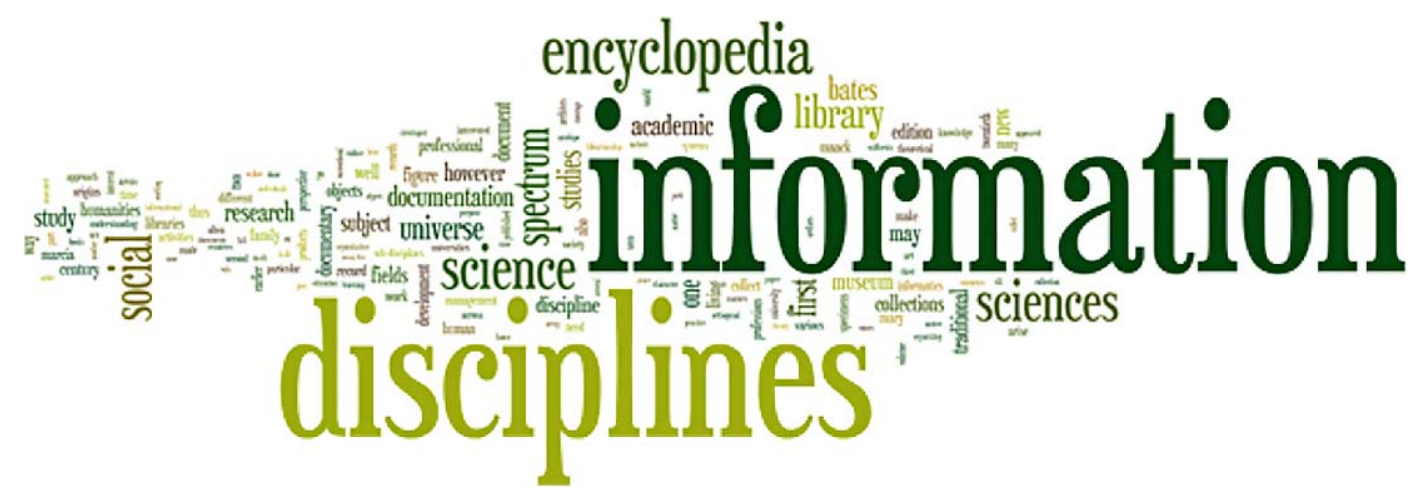

Fig. 1. Bates on the information disciplines [4]. (Colors are visible in the online version of the article; http://dx.doi.org/10.3233/ ISU-2012-0679.)

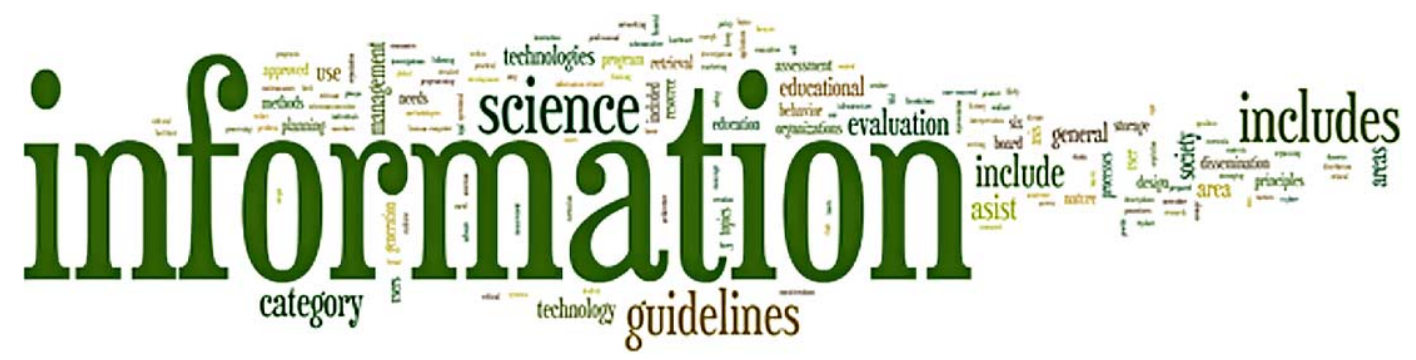

Fig. 2. ASIS\&T educational guidelines [3]. (Colors are visible in the online version of the article; http://dx.doi.org/10.3233/ ISU-2012-0679.)

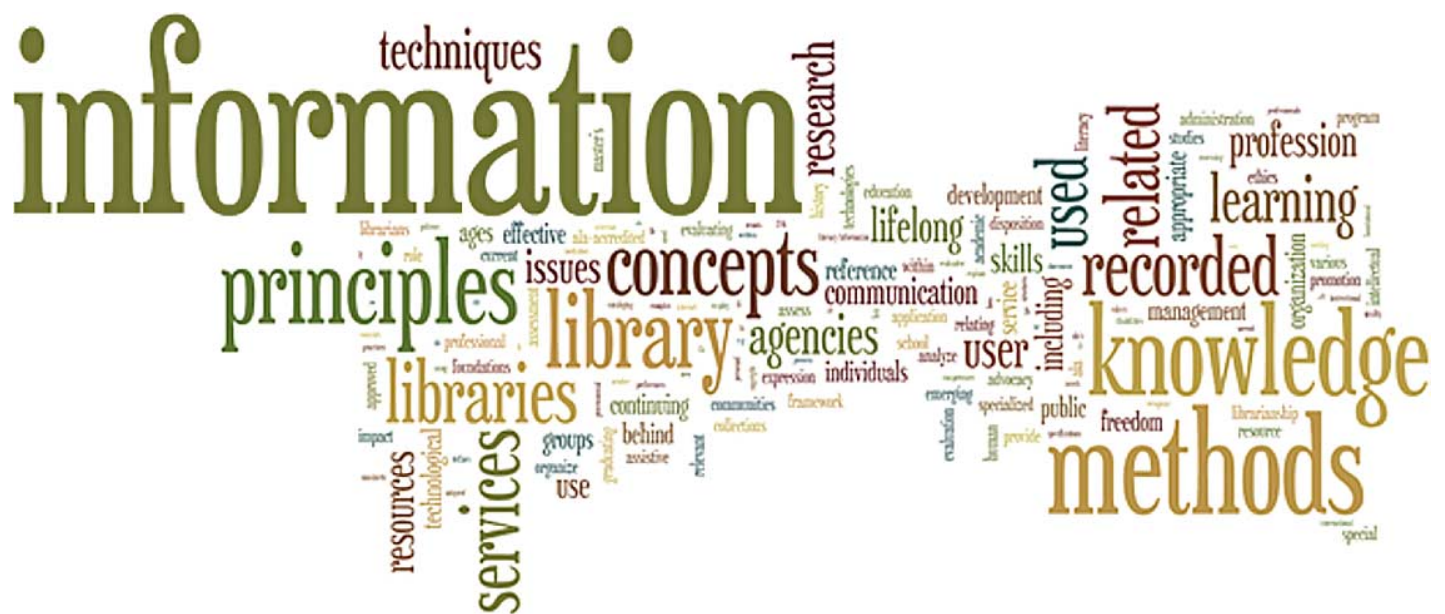

Fig. 3. ALA core competencies [2]. (Colors are visible in the online version of the article; http://dx.doi.org/10.3233/ ISU-2012-0679.) 


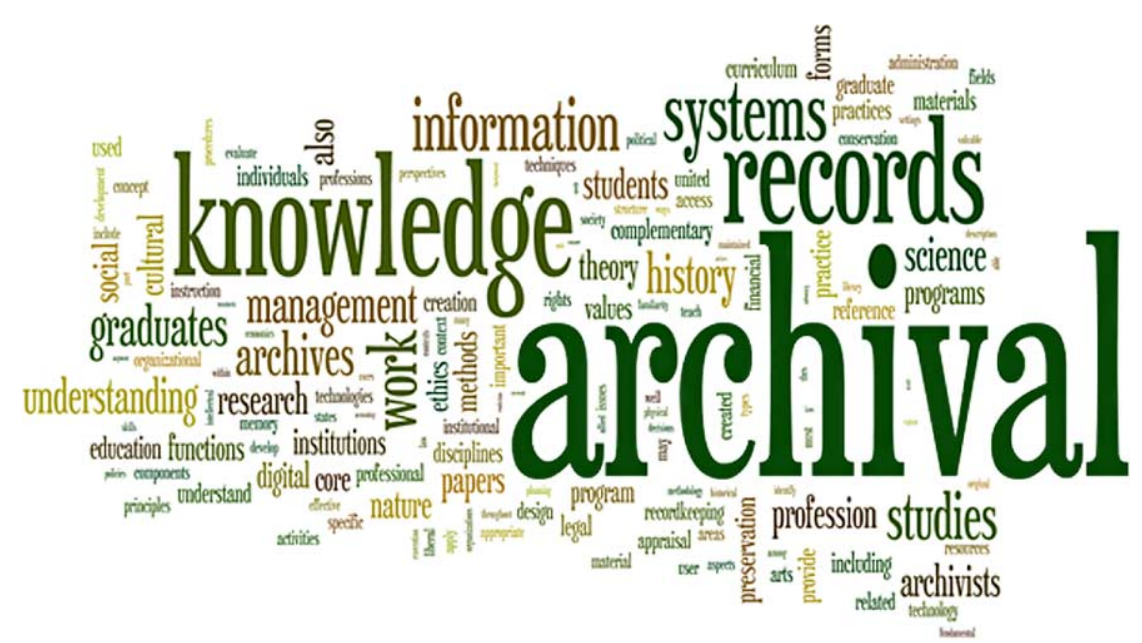

Fig. 4. Society of American archivists [10]. (Colors are visible in the online version of the article; http://dx.doi.org/10.3233/ ISU-2012-0679.)

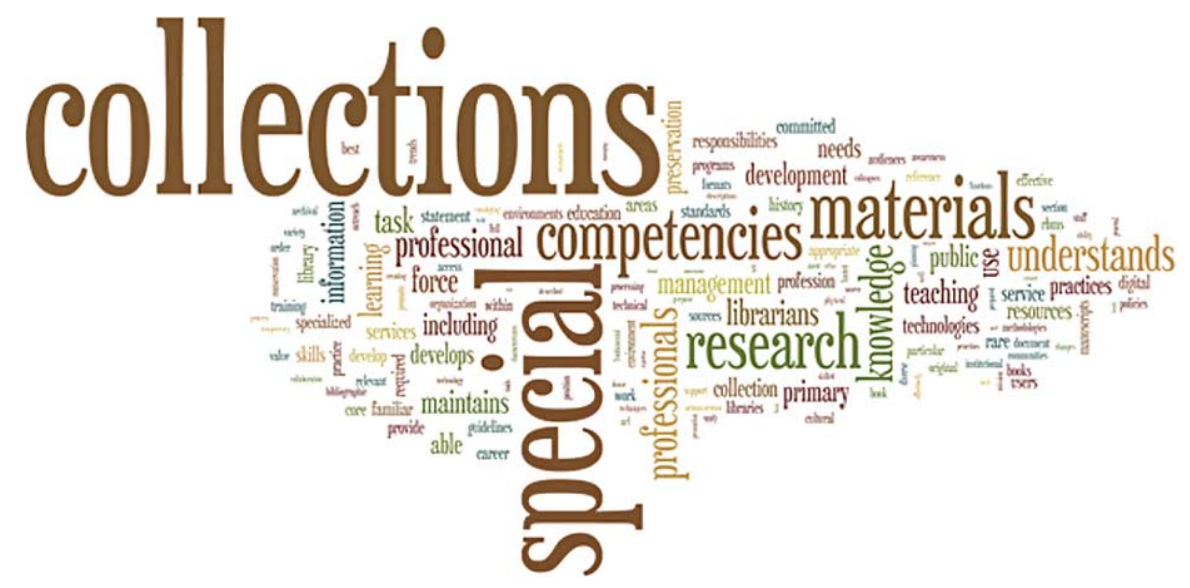

Fig. 5. Special collection professionals, ACRL [11]. (Colors are visible in the online version of the article; http://dx.doi.org/ 10.3233/ISU-2012-0679.)

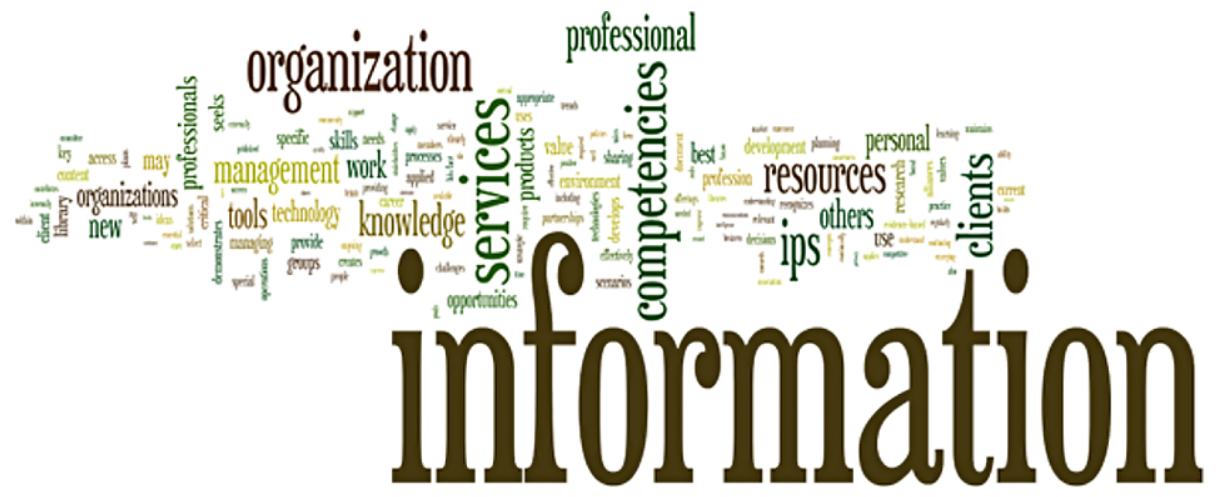

Fig. 6. Special Libraries Association [1]. (Colors are visible in the online version of the article; http://dx.doi.org/10.3233/ ISU-2012-0679.) 


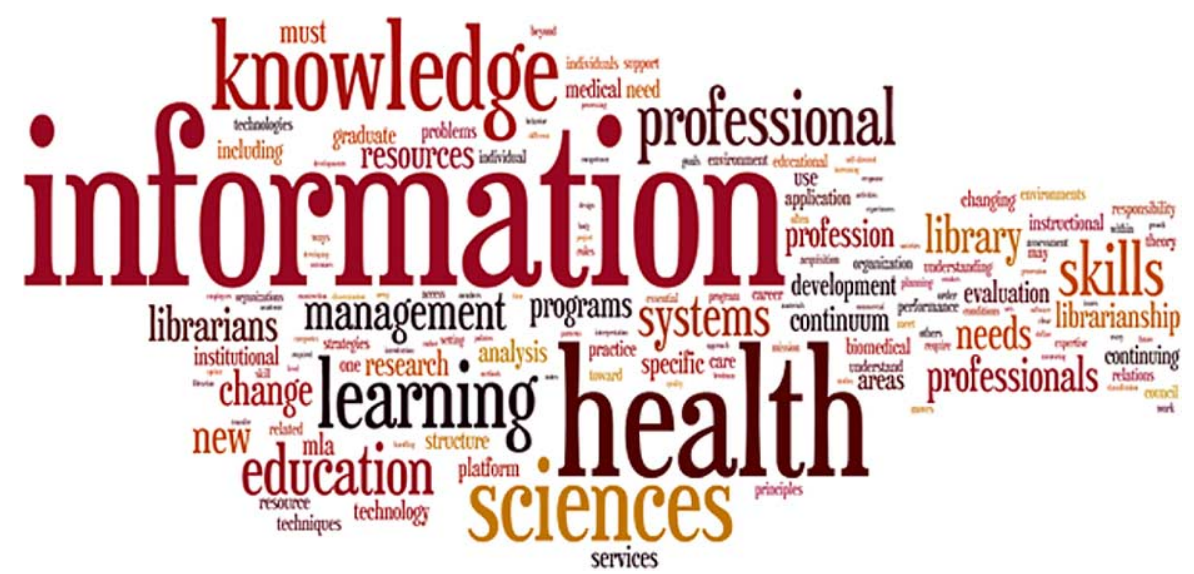

Fig. 7. Medical Library Association [8]. (Colors are visible in the online version of the article; http://dx.doi.org/10.3233/ ISU-2012-0679.)

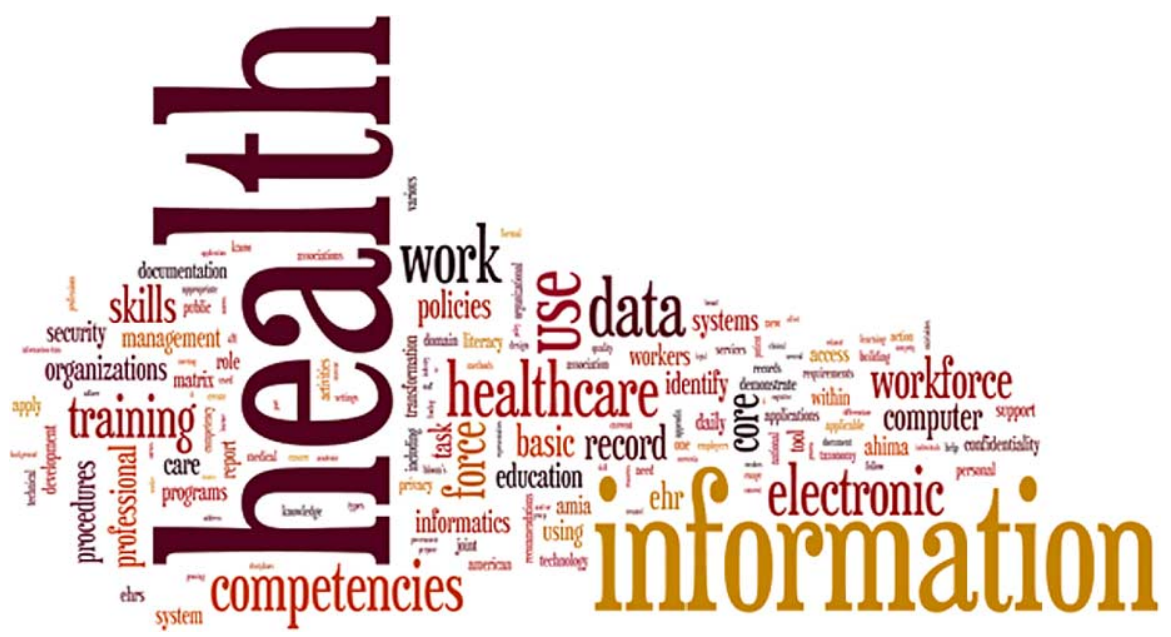

Fig. 8. Health Information Management [7]. (Colors are visible in the online version of the article; http://dx.doi.org/ 10.3233/ISU-2012-0679.)

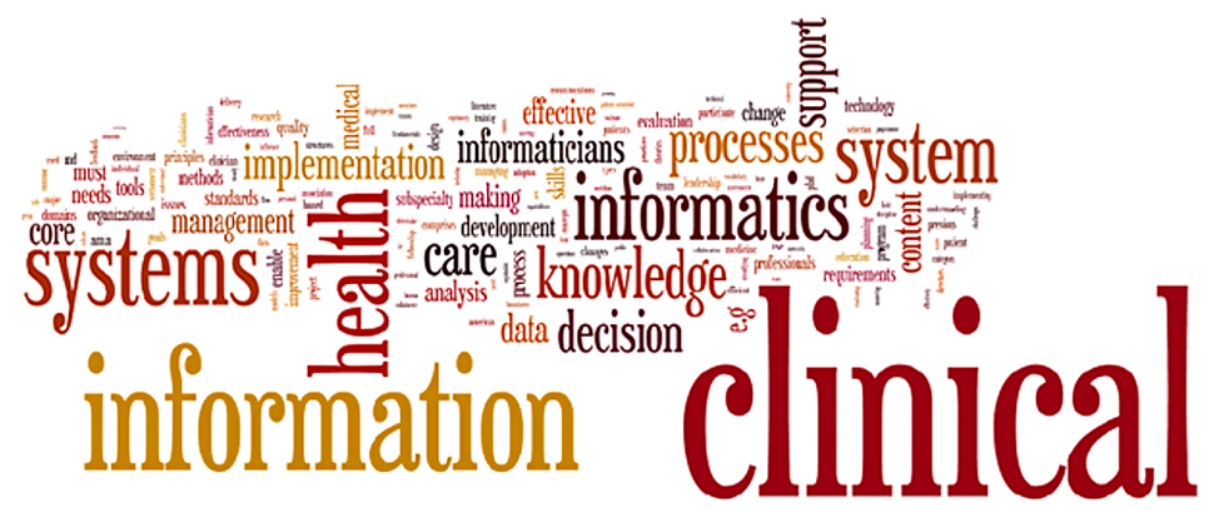

Fig. 9. Clinical informatics [5]. (Colors are visible in the online version of the article; http://dx.doi.org/10.3233/ ISU-2012-0679.) 


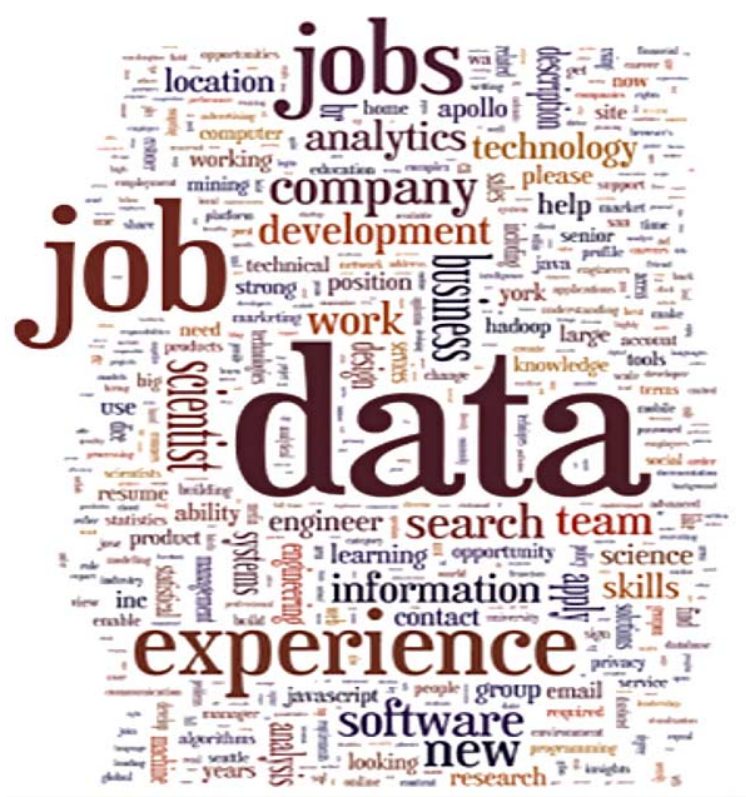

Fig. 10. Data sciences [6]. (Colors are visible in the online version of the article; http://dx.doi.org/10.3233/ISU-2012-0679.)

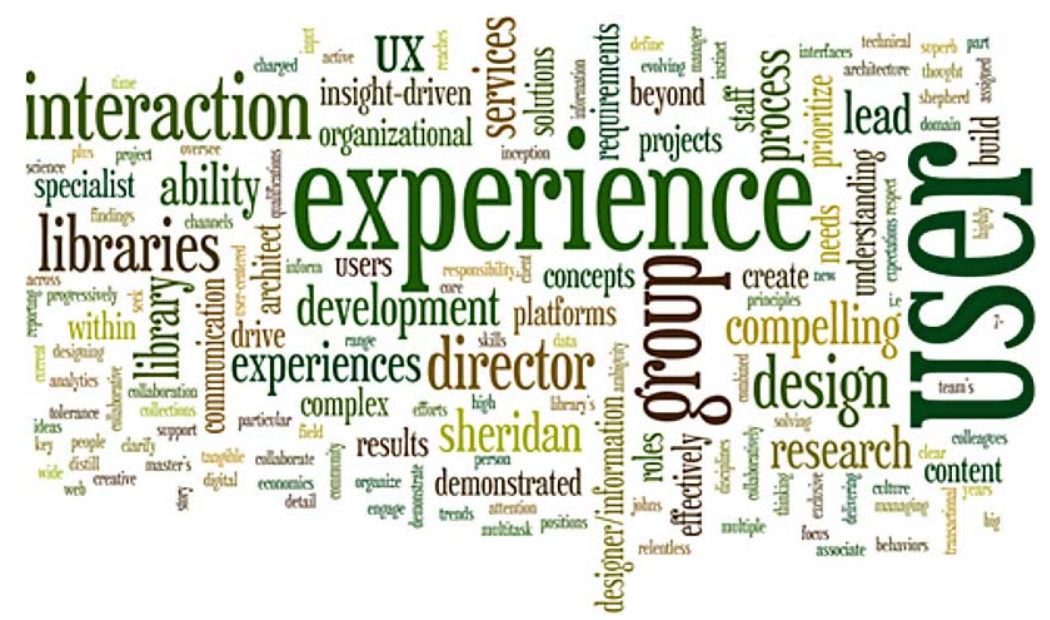

Fig. 11. User Experience Librarian [9]. (Colors are visible in the online version of the article; http://dx.doi.org/10.3233/ ISU-2012-0679.)

\section{References}

[1] E. Abels, R. Jones, J. Latham, D. Magnoni and J.G. Marshall, Competencies for information professionals of the 21st century, 2003, prepared for the Special Libraries Association Board of Directors by the Special Committee on Competencies for Special Librarians, available at: http://www.sla.org/content/learn/members/competencies/index.cfm.

[2] ALA's Core Competences of Librarianship, 2009, final version approved by the ALA Executive Board, October 25, 2008, approved and adopted as policy by the ALA Council, January 27, 2009, available at: http://www.ala.org/educationcareers/ sites/ala.org.educationcareers/files/content/careers/corecomp/corecompetences/finalcorecompstat09.pdf.

[3] C. Barry, D. Bilal, A. Wallace and B. Logan, ASIST educational guidelines, approved by the ASIST Board November 8 , 2001, available at: http://www.asis.org/Board/educational_guidelines.html. 
[4] M.J. Bates, Defining the information disciplines in encyclopedia development, Information Research 12(4) (2007), available at: http://InformationR.net/ir/12-4/colis/colis29.html.

[5] R.M. Gardner, J.M. Overhage, E.B. Steen, B.S. Munger, J.H. Holmes, J.J. Williamson and D.E. Detmer, AMIA Board of Directors, Core content for the subspecialty of clinical informatics, J. Am. Med. Inform. Assoc. 16(2) (2009), 153-157, Epub 2008 December 11.

[6] GilPress, What's the big data: A very short history of data science, posted 2012 April 26, available at: whatsthebigdata. com/2012/04/26/a-very-short-history-of-data-science.

[7] Joint Work Force Task Force, Heath information management and informatics core competencies for individuals working with electronic health records, AHIMA and AMIA, 2008, available at: http://www.ahima.org/schools/FacResources/ RESOURCEworkforce_2008.pdf.

[8] Medical Library Association, Platform for change: The educational policy statement of the Medical Library Association, 2007, available at: http://www.mlanet.org/education/platform/skills.html.

[9] Sheridan Libraries, User experience director job description, Johns Hopkins Univ., 2012.

[10] Society of American Archivists, Guidelines for a graduate program in archival studies, approved by the SAA Council, 2011, available at: http://www2.archivists.org/gpas/curriculum.

[11] Task Force on Core Competencies for Special Collection Professionals, Guidelines: Competencies for special collections professionals, approved by the ACRL Board, July 1, 2008, available at: http://www.ala.org/acrl/standards/ comp4specollect. 